\title{
An Asian Pivot Starts at Home: The Russian Far East in Russian Regional Policy
}

\author{
Helge Blakkisrud
}

Abstract To realize its ambitious goals of turning the Far East into Russia's gateway to the Asia-Pacific, the Kremlin in 2012 established the Ministry for the Development of the Far East. Structurally, this ministry is a hybrid, with offices at the federal and the regional levels, reflecting both Moscow's centralized take on policy formulation and the difficulties of micro-managing politics in a region distant in time and space. Analysing whether the new ministry has been a success, the author concludes that, while Moscow's primary goal has been to open a Far Eastern gateway, a side-effect might be that the Far East will become better integrated with the rest of the country, providing for more balanced development throughout the Federation.

Keywords Russian Far East • Ministry for the Development of the Far East

- Policymaking • Centre-periphery relations $\bullet$ Regional development

H. Blakkisrud $(\square)$

Research Group on Russia, Eurasia and the Arctic, Norwegian Institute of International Affairs, Oslo, Norway

(C) The Author(s) 2018

H. Blakkisrud, E. Wilson Rowe (eds.), Russia's Turn to the East,

Global Reordering, https://doi.org/10.1007/978-3-319-69790-1_2 
Russia's pivot to Asia starts at home. While the turn towards Asia is fuelled by expectations of reaping benefits from integrating with the fast-growing markets of Northeast Asia, undertaking such a geo-economic reorientation is not possible without a viable springboard, or gateway, in the Russian Far East. For all the talk about Asia-Pacific markets, a key component of the pivot is therefore developing Russia's own Far Eastern region, a territory 'uniquely endowed, but perennially troubled' (Lee and Lukin 2016, p.7), an underdeveloped, crises-ridden backwater that currently constitutes a 'double periphery'-in relation to Moscow and to the Asia-Pacific (Kuhrt 2012). The dire socioeconomic conditions-and the need to take action - have been acknowledged by the Kremlin. In 2013, Vladimir Putin in his annual address to Federal Assembly even declared the development (pod"em, lit. 'lifting up') of the Far East a 'national priority for the entire twenty-first century' (Putin 2013).

Making the Russian Far East a viable gateway to the East will require sustained and coordinated efforts. As Putin expressed it: 'The tasks to be solved are unprecedented in scale, and therefore also our steps must be non-standard' (Putin 2013). To realize its ambitious plans, Moscow came up with an institutional innovation: a new ministry, operating partly in Moscow as a regular part of the federal government, partly as a decentralized structure based in the Far Eastern Federal Okrug.

In general, Russian politics is informed by a long tradition of implementing top-down development models. This is not something that originated with the Soviet five-year plans: also in Tsarist Russia, the state took a lead in modernization and economic development, not least in the Russian Far East. In the post-Soviet period, this 'urge to plan' manifests itself in the belief that the state can organize itself out of problems through strategic planning, bureaucratic reorganization and targeted state programmes (Cooper 2012, p.1; Monaghan 2013). Unsurprisingly, the policymaking behind the 'turn to the East' also exhibits a strong continued commitment to strategic planning (Fortescue 2016, p.423).

At the same time, this top-down approach coexists with a fair amount of hands-on management, or 'manual control' (ruchnoe upravlenie). The authorities frequently have to resort to the latter due to the failure of the bureaucracy to implement plans or to tackle inter-ministerial/inter-agency rivalries (Monaghan 2013). Thus, the leadership and top officials 'are required to become involved in regional, even local issues, micromanaging, rather than focusing on strategic matters' (ibid., p.1235). 
The hybrid solution presented by the introduction of the Ministry for the Development of the Far East reflects an attempt to combine Moscow's traditionally centralized approach to policy formulation with bold acknowledgement of the difficulties of micro-managing policy implementation in a region extraordinarily distant both in time and space. ${ }^{1}$ This chapter traces the role and function of the new Ministry for the Development of the Far East. How does this body interact with the other parts of the executive branch that also oversee Far Eastern policy portfolios (other branch ministries, the Presidential Plenipotentiary to the Far Eastern Federal Okrug and the regional heads)? Do we find traces of an impact of the post-Crimea breakdown of Russo-Western relations in how Moscow has approached the internal dimension of the pivot? And to what extent can this institutional innovation be characterized as a success?

\section{Backdrop: Post-1991 Management of Centre-Region Relations}

Since the break-up of the Soviet Union, the Kremlin has struggled to produce a viable model for organizing centre-region relations. In 1990, Boris Yeltsin famously encouraged the regions to 'Take as much sovereignty as you can swallow.' This ushered in a decade of ad hoc decentralization and federalization of the Russian state - partly a desired development, and partly because of Moscow's greatly reduced capacities and resultant failure to fulfil its obligations vis-à-vis the regional level (Blakkisrud 2003). From the turn of the millennium, however, political priorities shifted. The transfer of power and responsibilities to the regional level was first halted, then replaced by far-reaching re-centralization (Ross 2002, 2010; Blakkisrud 2015).

The shifting priorities in centre-region relations are reflected in the way the federal government has sought to organize this administratively. The portfolio of regional policies has had a tumultuous history, at times coordinated by a separate body, at other times divided across various ministries. After the turn of the millennium, regional policy as a separate domain fell victim to Putin's centralization drive, and the ministry was abolished (see Table 2.1). However, during Putin's second term, as part of a concerted push towards strengthening state institutions, the Ministry of Regional Development was re-introduced. This heralded a relative stabilization of the institutional framework: for the next ten years, this ministry oversaw the implementation of regional policy within Russia's increasingly emasculated federalism. 
Table 2.1 Russian ministries responsible for regional policy

\begin{tabular}{ll}
\hline Name & $\begin{array}{c}\text { Years in } \\
\text { operation }\end{array}$ \\
\hline $\begin{array}{l}\text { State Committee on Federal Affairs and Nationalities } \\
\text { Ministry on Nationality Affairs and Regional Policy }\end{array}$ & $\begin{array}{l}1993-1994 \\
\text { Ministry on Nationality Affairs and Federal Relations }\end{array}$ \\
$\begin{array}{l}\text { Ministry on Regional and Nationalities Policy } \\
\text { Ministry on Regional Policy (nationality policy as separate ministry) }\end{array}$ & $1996-1998$ \\
$\begin{array}{l}\text { Ministry on Federal Affairs and Nationalities } \\
\text { Ministry on Federal Affairs, Nationalities and Migration Policy } \\
\text { (Goskomsever and migration service added) }\end{array}$ & $1998-1999$ \\
$\begin{array}{l}\text { No separate ministry (portfolio divided between Ministry of Internal } \\
\text { Affairs and Ministry of Economic Development) }\end{array}$ & $2009-2000$ \\
Ministry of Regional Development & $2001-2004$ \\
$\begin{array}{l}\text { No separate ministry, but ministries for the Far East (2012-), North } \\
\text { Caucasus (2014-) and Crimea (2014-2015) }\end{array}$ & $2004-2014$ \\
\hline
\end{tabular}

Source: RIA Novosti (2011); author's compilation

\section{The Russian Far East}

Regarding the Russian Far East, centre-region relations in the 1990s revolved around issues of regional autonomy, control over natural resources and federal tax policy (Lee and Lukin 2016, p.9). China was also a recurrent topic, with regional leaders in the Far East often less enthusiastic than Moscow politicians about the benefits to be gained from developing relations with neighbouring Chinese provinces (see, for example, Burles 1999, pp.43-47).

Most federal subjects in the Russian Far East are net recipients of transfers over the federal budget, heavily dependent on Moscow's subsidizing the local economy. During the economic upheaval of the 1990s, the gut reaction of regional leaders was to lobby Moscow for greater support rather than to seek to develop the region's comparative advantages in the wider Asia-Pacific region. However, with the economic crisis and empty state coffers, Moscow had little to offer but promises. In 1996 the federal government adopted a targeted programme for the development of the Russian Far East, but most plans never materialized. The reason was, according to Stephen Fortescue, a combination of lack of genuine commitment and lack of adequate resource allocation (Fortescue 2016, p.425). 
New attempts to revive the Far Eastern provinces were undertaken through new targeted programmes adopted in 2002 (focusing on exploitation of natural resources) and 2006 (living standards and social welfare) (Fortescue 2016, p.425). As the state finances gradually improved in the early 2000s, the problem of underfinancing became less acute. Especially with the adoption of the 2006 revision, the state began investing massively in the socioeconomic development of the Far East. Ambitious goals were set for economic growth, job creation, and renovation and expansion of existing infrastructure (Lee and Lukin 2016, p.9).

Another breakthrough came in 2009 when, in the midst of a new economic crisis, the government adopted a revised long-term development agenda for the Russian Far East: the 'Strategy for the Socioeconomic Development of the Far East and the Baikal Region for the Period until 2025' (Pravitel'stvo 2009). The Strategy highlighted the potential for regional economic development through integration with the Asia-Pacific region, by supplying countries like China, Japan and South Korea with energy and natural resources.

Based on an understanding that only the state and state-owned corporations had the economic muscle necessary for implementing such a grand project, the idea of setting up a special state corporation for the development of Eastern Siberia and the Russian Far East was floated in the run-up to Putin's third presidential term. ${ }^{2}$ This corporation would be responsible for ensuring efficient exploitation of the region's natural resources and be under direct presidential oversight (Mel'nikov et al. 2012). It would enjoy wide powers: federal legislation would partly be set aside, to be replaced by a special economic regime for 16 federal subjects in the Far East and Eastern Siberia (encompassing about 60 per cent of all the territory of the Russian Federation).

However, the idea was controversial-among the general public and within the government. It drew criticism for attempting to introduce something akin to a 'state within the state' (Mel'nikov et al. 2012) and, through its emphasis on state-managed resource extraction, for reminding the local population about the region's status as an 'exploited semicolonial periphery' (Lee and Lukin 2016, p.84). A draft law for establishing such a corporation was shelved, and in its place came the Ministry for the Development of the Far East. 


\section{The Ministry for the Development of the Far East}

The new ministry was established in June 2012. For the first two years of its existence, it functioned in parallel to the Ministry of Regional Development. The rationale for lifting the Far Eastern portfolio out of regular regional development policy was the belief in top-down implementation of development: that a separate bureaucratic structure would offer the most efficient way of addressing the socioeconomic challenges of the Russian Far East. This new ministry was tasked with coordinating and monitoring the implementation of existing policies, as well as elaborating a new set of mechanisms for stimulating economic and social development in the Far East. To give additional clout to the new minister, it was also decided that the minister should double in the position as Presidential Plenipotentiary to the Far Eastern Federal Okrug.

The most innovative aspect of the new ministry was its partially decentralized structure, with the ministry physically being set up in Moscow and Khabarovsk and the minister dividing his time between the two branches. In fact, the initial plan had been to make the Khabarovsk branch the main one, with 200 out of a total staff of 240 being located there (Netreba 2012). The rationale was obvious: the Russian Far East, in itself spanning four time-zones (Yakutsk, Vladivostok, Magadan and Kamchatka), was simply too far away from Moscow to be micro-managed from the capital. Setting up a decentralized structure that ensured a regional presence was intended to make the new ministry better positioned to follow up implementation of state priorities and programmes in the field, as well as get a better grasp of regional challenges and potentials. And since Khabarovsk was the seat of the Presidential Plenipotentiary, the natural choice was to co-locate the ministry there.

The first Minister of Far Eastern Development was Viktor Ishaev, a local political heavyweight who had served as governor of Khabarovsk Krai from 1991 to 2009, when he was made Presidential Plenipotentiary to the Far Eastern Federal Okrug. Now he would combine the two jobs: as minister of the federal government and the president's special representative to the Far East. The recruitment of a minister with more than 20 years of first-hand experience from the regional executive branch seemed to signal that Moscow was now ready to allow room for regional inputs.

Within a few months, however, Ishaev fell out of favour with Putin for his failure to move forward in implementing the government's Far Eastern policy (Zav'ialova 2012; Fortescue 2016, p.443). In August 2013 he was 
replaced, both as minister and as presidential plenipotentiary, and the two positions were then split. The new minister was Aleksandr Galushka, recruited from Putin's All-Russian National Front, where he had been cochair. Unlike Ishaev, Galushka was a Muscovite with no experience from the Far East beyond having served for a year in the State Commission for the Socioeconomic Development of the Far East (2011-2012). As we will see below, the position of plenipotentiary went to Iurii Trutnev, a longterm Minister of Natural Resources (2004-2012).

In parallel, the ministry itself underwent structural reorganization, with an additional branch being set up in Vladivostok. In the process, staffing at the Khabarovsk branch, Ishaev's old stronghold, was cut back from more than 200 to a mere 28, while the new branch in Vladivostok was assigned 129 (compared to Moscow's 120) (Deita 2014). In December 2016, the organizational structure was further tempered by the decision to open a small 'mobile' office in Petropavlovsk-Kamchatskii (RIA Novosti 2016).

At the time, the ministry hinted that in future all nine federal subjects in the Far Eastern Federal Okrug might get their own branches of the ministry. This could have implications for the way the ministry functions. Today, the Khabarovsk and Vladivostok offices are officially equal in status to the Moscow one, although, with the shift from Ishaev to Galushka, the minister seems to be spending more time in Moscow. Within the ministry there is no clear branch specialization whereby a separate portfolio is allocated exclusively to Khabarovsk or Vladivostok: instead, there is regional representation to facilitate the flow of information and decisions between the capital and the federal subjects. ${ }^{3}$

\section{Portfolio}

According to the website of the Ministry for the Development of the Far East, it is responsible for the implementation of state programmes and federal targeted programmes in the Far Eastern Federal Okrug, the management of federal property and monitoring the work of the regional executive branch. ${ }^{4}$

The main focus of the ministry is reflected in its organizational structure. Besides departments for administration and control, it includes the following divisions, as of March 2017: 
- Department for Complex Macro-Regional Development, Attracting Budget Financing and Public Investment

- Department for Attracting Private Investment

- Department for Infrastructure Development

- Department for Advanced Special Economic Zones (ASEZs) and the Free Port of Vladivostok

- Department for Development of Human Capital and Territorial Development.

Within the portfolio of the ministry are also the following agencies:

- the Far East Human Capital Development Agency, established in September 2015 with offices in Moscow, Khabarovsk and Vladivostok, and tasked with attracting labour force to the Russian Far East and facilitating positive migration dynamics; ${ }^{6}$

- the Far East Investment and Export Agency, established in September 2015 with an office in Moscow, responsible for marketing the region and working with potential national and international investors, including potential residents of the ASEZs;

- the joint stock company Far East Development Corporation, established in April 2015 with offices in Moscow and Vladivostok, handling the operation of the ASEZs and development of the Free Port of Vladivostok regime. ${ }^{7}$

On the whole, this is a watered-down portfolio, as compared to the lofty plans for a state corporation. Not only has the territory falling under the purview of the ministry been nearly halved (when Eastern Siberia was excluded, the figure fell from some 60 per cent of Russia's territory to 36 per cent), the powers and prerogatives were also cut back to something more resembling a regular ministry: its current portfolio is more about oversight and facilitating development than being directly involved in running Far Eastern businesses. Nataliia Zubarevich, one of Russia's leading experts on centre-region relations, thus argues that the ministry proved

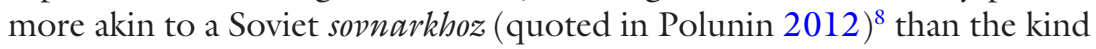
of super-ministry some people initially had speculated that it might become (Netreba 2012). 


\section{Plans and Implementation}

While the powers of the ministry were reduced as compared to what key actors behind the idea of a state corporation had envisioned, what the new ministry initially did enjoy was impressive economic muscle. In March 2013, during Ishaev's stint as minister, an ambitious new state programme with a total budget more than 10 trillion rubles, of which the government was to contribute 3.8 trillion, was adopted (Gorshkova 2013). For the period up until 2025, the state was to spend lavishly on realizing what Stephen Fortescue has called a 'resource-oriented monster' by implementing 'a huge catalog of projects, many of which had been bandied around and included in funding wish lists since Soviet times' (Fortescue 2016, p.431).9

Economic realities soon kicked in, however. With the change in leadership in the ministry, the plans were overhauled and ambitions were cut back. Prime Minister Dmitrii Medvedev openly admitted that the previous development models had failed:

We must admit frankly that all approaches, all the models that we have used in recent years, in order to change the development of the Far East radically, have not been unequivocally successful, they have not yet brought the results we expected, they have not produced economic effects. (Government. ru 2013)

In April 2014, when a revised version of the programme was adopted, the state funding for the period up to 2020 had been reduced to 346 billion rubles (Government.ru 2014) - to less than a tenth of what the government had pledged the previous year. Gone were the extravagant state-funded investment projects pushed by Ishaev; the focus was now on attracting private investment-national and foreign-to accelerate the economic development in the Russian Far East. In the course of the next year, several new mechanisms were introduced to facilitate the influx of capital-both financial and human-into the Far Eastern Federal Okrug. Three key initiatives deserve to be highlighted in this respect.

First, there is the establishment of advanced special economic zones (ASEZs), introduced in March 2015. ${ }^{10}$ The ASEZs are based on deregulation and tax breaks working as incentives for attracting private investment. The idea is for these specialized zones to serve as growth engines for the wider region (Turovskii 2016). The ASEZs are nominated by the ministry 
and operated by the Far East Development Corporation (see Min and Kang, Chap. 4, this volume, for a detailed discussion).

Second, there is the Free Port of Vladivostok, which was signed into law in 2015, turning 15 municipalities in the southern part of Primorskii Krai into a special economic zone. The Free Port regime encompasses $28,400 \mathrm{~km}^{2}$ and 1.4 million people. Like the ASEZs, it involves tax and customs benefits and simplified regulations - in this case, also potentially a special simplified visa regime. The Free Port is, however, far more ambitious in scale and complexity. The plans involve creating 85,000 new workplaces by 2021 and more than doubling the GRP of Primorskii Krai by $2025 .{ }^{11}$ As with the ASEZs, the regime is operated by the Far East Development Corporation.

Third, there is the Far Eastern hectare initiative, introduced in 2016 to counteract the negative migration balance. The population of the Russian Far East has dropped year on year ever since the break-up of the Soviet Union. By offering land for free, the authorities hope to attract settlers to move to the more fertile southern parts of the federal okrug. Since 1990 the area of cultivated arable land in the Russian Far East has decreased by a factor of 2.3 (Lee and Lukin 2016, p.48). To recover this land, increase regional self-sufficiency in food production as well as boost the population, prospective farmers will get one hectare for free, on the condition that they begin to cultivate the land within five years. ${ }^{12}$ The mechanism is administered by the Far East Human Capital Development Agency and was initially reserved for locals, but from I February 2017 has been open to all citizens of the Russian Federation. ${ }^{13}$

The ministry has thus come up with a set of mechanisms aimed at improving the local investment climate, hoping to give the regional economy the boost it so desperately needs if the Far East is to function as a gateway to the Asia-Pacific. Due to sequestration and changing priorities, state spending earmarked for Far Eastern development has been slashed several times over the last few years, ${ }^{14}$ making such private contributions even more crucial.

\section{INSTITUTIONAL ENVIRONMENT}

The Ministry for the Development of the Far East is responsible for coordinating state policies for economic and sociodemographic development of the Far Eastern Federal Okrug, but it operates in an institutional landscape within the executive branch that involves a series of other actors with 
partially overlapping portfolios - if not always fully overlapping interests. The most important of these actors are as follows: other federal ministries as well as the deputy prime minister coordinating Far Eastern policy, the Office of the Presidential Plenipotentiary to the Far Eastern Federal Okrug, the State Commission on the Socioeconomic Development of the Far East and - at the regional level— the governors.

\section{Intra-Ministerial Competition and Rivalvies}

Most immediately, the Ministry for the Development of the Far East faces intra-ministerial competition within the federal government. Until the Ministry of Regional Development was abolished in 2014, there was a potential tension between priorities in regional development as such and specific prioritization of the Russian Far East. In November 2012, President Putin, at a meeting of the Presidium of the State Council devoted to the development of the Far East, castigated the two ministries for their failure to implement the transfer of relevant federal programmes, which, he went on to say, had resulted in 'blurred responsibilities', lack of progress in the work, and the Ministry for the Development of the Far East 'still not justifying its existence' (Kremlin.ru 2012). ${ }^{15}$

However, even with the Ministry of Regional Development gone, there remain other real and potential overlaps-for example, with the priorities of the Ministry of Natural Resources or the Ministry of Economic Development. The latter, which coordinates Russia's special economic zones (SEZs), has questioned the efficiency of the new ASEZ regime, arguing that the new workplaces created come with a price tag of 6 million rubles, money that could be spent more efficiently on creating 'regular' jobs (Lossan 2014). Economic development is also the portfolio of First Deputy Prime Minister Igor Shuvalov, who has taken a keen interest in the development of the Russian Far East-whereas, as we will see below, since 2013 the Far East has been represented in the government by a separate Deputy Prime Minister, Iurii Trutnev.

Not surprisingly, there have also been repeated clashes with the Ministry of Finance over funding. For example, the latter was seen as attempting to torpedo Ishaev's ambitious but costly plans for the development of the Russian Far East, with Minister of Finance Anton Siluanov arguing that the proposed state contribution 'was 14 times more than his ministry considered realistic' (Fortescue 2016, p.432). Over time, the Ministry of Finance has tightened the purse-strings considerably, most recently with 
an almost 50 per cent cut in spending on the state targeted programme in 2017 as compared to the previous year (PrimaMedia 2016). According to Galushka, it was only the direct intervention of Putin that prevented even deeper cuts at this stage (TASS 2016).

\section{Oversight Versus Overlap: The Role of the Presidential Plenipotentiary}

Ishaev combined being Minister for the Development of the Far East with serving as the personal representative of the Russian President to the Far Eastern Federal Okrug. The task of the presidential plenipotentiary is to monitor implementation of Moscow's policies in the subjects within the federal okrug in question. In case of the Far Eastern Federal Okrug, the territorial area of responsibility of the plenipotentiary overlaps with that of the Ministry for the Development of the Far East. In other words, Ishaev was responsible for monitoring the work of his own ministry.

When in 2014 Ishaev was replaced by Trutnev, checks and balances were only partially restored: while Trutnev was not given charge of the ministry itself, he was made Deputy Prime Minister with responsibility for the Russian Far East. Trutnev would thus ensure the coordination of the interests of the presidential administration and the government. Besides enjoying direct access to the President, Trutnev holds a more senior position in the cabinet than Galushka: as Deputy Prime Minister he can issue directives regarding his portfolio to any federal minister. Thus, Galushka has been relegated to a more subordinate position when it came to setting the priorities for Far Eastern development. Increasingly, Trutnev and his staff seem to be taking the lead in developing new initiatives here.

\section{Bureaucratization and Duplication}

In order to facilitate coordination of state policies on the Far East, in June 2012 , in parallel to the establishment of the ministry, a separate state commission for the socioeconomic development of the Far East, Buryatia, Zabaikal Krai and Irkutsk Oblast was introduced under the chairmanship of First Deputy Prime Minister Shuvalov. In September 2013, the commission was revamped, and the territorial delimitation changed so as to coincide fully with that of the portfolio of the Ministry for the Development of the Far East. In its new incarnation, the commission is chaired by Prime Minister Medvedev himself, and includes relevant minis- 
ters, regional heads from the Far East and fairly broad participation of major business actors (Gazprom, Mechel, RusHydro, Rosneft, Transneft, Sberbank and others). ${ }^{16}$

The State Commission on the Socioeconomic Development of the Far East meets at least once every six months to discuss draft strategies, programmes and policies for the socioeconomic development of the Russian Far East, as well as to determine priorities for investment projects (Rossiiskaia gazeta 2013). As such, it serves to anchor the priorities in a wider group of key actors beyond the government-but this arrangement may also slow down the decision-making process, as plans and priorities of the Ministry for the Development of the Far East must be approved here before the ministry can move forward. The personal involvement of Putin in Far Eastern politics (Fortescue 2016, p.441) serves as a guarantee against Moscow slipping back into its traditional relative political and economic neglect of the Russian Far East. However, with Prime Minister Medvedev taking a lead in, for example, the improvement of the Far Eastern investment climate (Wegren et al. 2015), Deputy Prime Minister Trutnev carrying overall responsibility for coordinating Far Eastern development and Galushka being in charge of the relevant ministry, there is a risk of duplication, inefficient resource management and a certain marginalization of the ministry itself.

\section{The Regional Executive}

At the regional level, the most important counterparts to the Ministry for the Development of the Far East are the regional heads of executive power, the governors and-in the case of Sakha - the head of the republic. Under the administrative-institutional reforms of the 1990s, the regional executive branch became the centre of political power at the federal subject level. Towards the end of the decade, the regional heads were likened to 'the boyars of the old, apparently insulated from the writ of federal laws and the constitution', turning their federal subjects into 'separate fiefdoms' (Sakwa 2002, p.16). One of the most glaring examples of such wilful regional rulers was Governor Evgenii Nazdratenko of Primorskii Krai (1993-2001), the bête noire of Russian regional politics in the 1990s, who repeatedly challenged the Kremlin's right to intervene in regional power politics.

With the onset of Putin's presidency, however, the Kremlin started pushing back the concessions the regional heads had won during the pre- 
vious decade, a process that culminated with the 2004 decision to reintroduce presidentially appointed governors (Blakkisrud 2015). In 2012, the Kremlin again decided to slacken the reins, allowing a return to direct elections. In practice, however, the presidential administration has continued to control gubernatorial turnover, with elections serving more as referenda over the Kremlin's choice of candidates.

Deprived of a strong independent power-base, today the power and influence of the regional heads are largely a function of their connections and lobbying potential in Moscow. However, while formally an integrated part of the 'executive vertical', this does not prevent ambitious regional heads from launching their own projects that may compete, overlap with or duplicate the work of the Ministry for the Development of the Far East. ${ }^{17}$ The ministry has also been criticized for not consulting sufficiently with regional actors, for example, when designating new ASEZs (see Troyakova, Chap. 3, this volume). It thus appears that bringing the ministry closer to the regions by maintaining a decentralized structure has not shielded it from criticism for failing to take local conditions and input into consideration in the planning process.

\section{Ministry for the Development of the Far East: Successes ANd Pitfalls}

The Putin-era approach to the Russian Far East has 'marked a significant departure from the traditional posture of selective inattention or even outright neglect by the central government' (Lee and Lukin 2016, p.9). However, the post-Crimea crisis in relations with the West has not been the primary driver, although it may have added a sense of greater urgency to the pivot. As we have seen, concerted efforts to accelerate socioeconomic development, as well as to open up the region as a gateway for exports to the Asia-Pacific, predated the introduction of Western sanctions. Already by the summer of 2012, the main institutional framework for the internal dimension of the turn to Asia was in place, with the establishment of the Ministry for the Development of the Far East. And, whereas specific mechanisms for attracting private investment and people to the Far Eastern Federal Okrug have been established only in the last couple of years, the marching orders had been given far before the Crimean situation developed. In fact, if we look at fiscal investment in this endeavour, the postCrimea period has been marked by a steady decline in state involvement. 
Peaking with the adoption of Ishaev's grandiose state programme in 2013, state funding and promises have been cut back, year after year. Even if the federal budget is currently under strong pressure, this certainly gives rise to some questions about Moscow's long-term commitment to the pivot.

What has been achieved over the past few years is that the new development model for the Russian Far East has been institutionally anchored. Uncertainty remains, however, as to whether the institutional model devised by the Kremlin will prove capable of dealing with the fundamental problems facing the Russian Far East. The process is still characterized by Moscow's firm penchant for strategic planning and pursuing statesponsored, top-down development models-even the (partially) decentralized Ministry for the Development of the Far East seems to be sliding back to the traditional Moscow-centred model. In parallel, the bureaucracy has multiplied, while political ownership of the processes has become diffused.

It could also be argued that most of the new mechanisms introduced have already been tried and tested. The most basic problems that the Ministry for the Development of the Far East is struggling with are essentially the same as those that have plagued the Russian Far East ever since the territory fell under Russian control-as are the basic tenets of the solutions that have been proposed. In 1909, for example, Prime Minister Petr Stolypin introduced a Committee on Resettlement to the Far East and, in the 1920s, the Soviets established a Far Eastern Migration Department. Similarly, Vladivostok was under a free port regime from 1861 to 1909.

Will the Ministry for the Development of the Far East succeed where others have failed, and manage to lift the Far East to same level of socioeconomic development as the rest of the Russian Federation? Although local observers complain that they have still not seen any economic effects of the new development mechanisms in the form of the creation of new jobs or increased tax revenues (see Troyakova, Chap. 3, this volume), it might not be fair to attempt to draw firm conclusions at this stage- as of this writing, the main mechanisms of the new development model have been in place for less than two years. While Vladivostok is hardly likely to become a future capital of Russia-as was suggested by Sergei Karaganov, a key conceptual strategist behind Russia's pivot (Karaganov 2012), the new interest in turning the Russian Far East into an Asia-Pacific gateway may still have the side-effect of integrating the Far Eastern federal subjects more closely with the rest of the country, providing for more balanced 
development throughout the Federation. But both tracks- the internal and the external dimension of the pivot-will need long-term commitment from Moscow if they are to yield results.

\section{Notes}

1. The vast territory of the Far East is located from six to nine time-zones ahead of Moscow; the distance from Moscow to PetropavlovskKamchatskii, the capital of Kamchatka Krai, is about 6780 kilometres. For comparison, the distance between Moscow and Quebec is not much greater: 6840 kilometres.

2. The main sponsor of this idea was Sergei Shoigu, Minister of Emergency Situations, who was seen as a potential head of the corporation (Gazeta.ru 2012). Instead, Shoigu was made governor of Moscow Oblast and later that same year promoted to Minister of Defence.

3. The observations in this paragraph are based on informal conversations with Russian experts on the Russian Far East from Moscow and Vladivostok.

4. See http://minvr.ru/about/ministry.php. Accessed on 10 March 2017.

5. For more details on the organizational structure, see http://minvr.ru/ about/struct.php?SECTION_ID=182. Accessed on 10 March 2017.

6. For a full description, see the agency website, http://hcfe.ru/about/general-information. Accessed 10 March 2017.

7. See the company's website at http://erdc.ru/. Accessed on 10 March 2017.

8. The sovnarkhozes, or regional economic soviets, were introduced by Nikita Khrushchev in 1957 in an attempt to counteract the centralization and departmentalization of union ministries. Each sovnarkhoz had planning and operational responsibility in a given region. The sovnarkhozes were abolished in 1965.

9. For an overview of the various sub-programmes see http://government. $\mathrm{ru} / \mathrm{en} / \mathrm{docs} / 1158$. Accessed on 14 March 2017.

10. Officially these zones are designated as territoriia operezhaiushchego sotsial'no-ekonomicheskogo razvitiia, or 'territories for advanced socioeconomic development'.

11. For information on the free port regime, see the webpages of the Eastern Economic Forum at https://forumvostok.ru/en/mesto/about-freeport. Accessed on 15 March 2017.

12. The initiative extends to the whole of the Far Eastern Federal Okrug. Land use is not limited to agriculture: the prospective owner may pursue other business models, such as construction or tourism. 
13. The application process and selection of the desired plot are done online and can be completed in a few clicks, see link to the Far Eastern hectare on http://minvr.ru. Accessed on 14 March 2017.

14. See PrimaMedia 2016 for more detail on the numerous cuts in state funding.

15. According to Deputy Prime Minister Iurii Trutnev, the transfer of powers and competencies to the Ministry for the Development of the Far East encountered resistance from other branch ministries (Gabuev and Mel'nikov 2014).

16. For the most recent composition of the commission, see http://government.ru/info/25386. Accessed on 16 March 2017.

17. See, for example, the mission statement of the Primorskii Krai Investment Agency at https://pkia.ru/ob_agentstve/missia_celi_zadachi/?lang=ruRU. Accessed on 20 March 2017. The agency was established by Governor Vladimir Miklushevskii in 2012.

\section{REFERENCES}

Blakkisrud, Helge. 2003. 'The rise and fall of the Russian governor: institutional design vs. elite bargaining as explanatory factors in Russian politics', in Elites and democratic development in Russia, edited by Anton Steen and Vladimir Gel'man, 71-91. London: Routledge.

Blakkisrud, Helge. 2015. The governor's last stand: federal bargaining in Russia's transition to appointed regional heads, 2005-2009. Oslo: University of Oslo.

Burles, Mark. 1999. Chinese policy toward Russia and the Central Asian republics. Santa Monica, CA: RAND.

Cooper, Julian. 2012. Reviewing Russian strategic planning: the emergence of Strategy 2020. Rome: NATO Defense College.

Deita. 2014. 'Samoe krupnoe podrazdelenie Minvostokrazvitiia razmestiat vo Vladivostoke' [The biggest subdivision of the Ministry for the Development of the Far East to be located in Vladivostok], 21 February. http://deita.ru/ news/politics/21.02.2014/4652297-krupneyshee-podrazdelenie-minvostokrazvitiya-poyavitsya-vo-vladivostoke. Accessed on 7 February 2017.

Fortescue, Stephen. 2016. 'Russia's "turn to the east": a study in policy-making', Post-Soviet Affairs 32(5): 423-54.

Gabuev, Aleksandr and Kirill Mel'nikov. 2014. 'Blizhaishaia zadacha - eto peredacha polnomochii' [The most immediate task is a transfer of power], Kommersant 17 February. http://kommersant.ru/doc/2410187. Accessed on 7 February 2017. 
Gazeta.ru. 2012. 'Goskorporatsiia podoshla k granitse' [The state corporation approaches the border], 21 January. https://www.gazeta.ru/business $/ 2012 / 01 / 21 / \mathrm{kz} 3970553 . s h t m l$. Accessed on 10 March 2017.

Gorshkova, Olga. 2013. 'Who will pay to develop the Russian Far East?' Russia Beyond the Headlines, 3 April. http://rbth.com/business/2013/04/03/ who_will_pay_to_develop_the_russian_far_east_24583.html. Accessed on 14 March 2017.

Government.ru. 2013. 'Pravitel'stvennaia komissiia po voprosam sotsial'noekonomicheskogo razvitiia Dal'nego Vostoka' [State Commission on the Socioeconomic Development of the Far East], 24 October. http://government.ru/news/7718. Accessed on 21 March 2017.

Government.ru. 2014. 'Ob utverzhdenii novoi redaktsii gosudarstvennoi programmy “Sotsial'no-ekomicheskoe razvitie Dal'nego Vostoka i Baikal'skogo regiona" [On the approval of a new version of the state programme 'On the Socioeconomic Development of the Far East and the Baikal region'], 15 April. http://government.ru/docs/11959. Accessed on 19 December 2016.

Karaganov, Sergei. 2012. 'Rossiia nuzhna eshche odna stolitsa - sibirskaia' [Russia needs another capital - a Siberian one], Rossiiskaia gazeta, 17 May. https:// rg.ru/2012/05/16/stolica-site.html. Accessed on 21 March 2017.

Kremlin.ru. 2012. 'Zasedanie prezidiuma Gossoveta' [Meeting of the presidium of the State Council], 29 November. http://kremlin.ru/events/president/ news/16990. Accessed on 9 November 2017.

Kuhrt, Natasha. 2012. 'The Russian Far East in Russia's Asia policy: dual integration or double periphery? Europe-Asia Studies, 64(3): 471-93.

Lee, Rensselaer and Artyom Lukin. 2016. Russia's Far East: new dynamics in Asia Pacific and beyond. Boulder, CO: Lynne Rienner.

Lossan, Alexei. 2014. 'Seven large foreign investors are to come to Russian Far East', Russia Beyond the Headlines, 20 September. http://rbth.com/business $/ 2014 / 09 / 20 /$ seven_large_foreign_investors_are_to_come_to_russian_ far_east_39979.html. Accessed on 20 February 2017.

Mel'nikov, Kirill, Aleksandr Gudkov and Aleksandr Panchenko. 2012. 'Vsia vlast' Sibiri' [All power to Siberia], Kommersant, 20 April. http://www.kommersant.ru/doc/1919404. Accessed on 7 February 2017.

Monaghan, Andrew. 2013. 'Putin's Russia: shaping a “grand strategy"? International Affairs, 89(5): 1221-36.

Netreba, Petr. 2012. 'Dal'nevostochnaia konfederatsiia' [The Far Eastern Confederation], Kommersant, 4 June. http://www.kommersant.ru/ doc/1950814. Accessed on 7 March 2017.

Polunin, Andrei. 2012. 'N. Zubarevich: Minvostokrazvitiia - eto novyi sovnakhoz' [N. Zubarevich: The Ministry for the Development of the Far is a new sovnarkhoz], Svobodnaia pressa, 4 June. http://svpressa.ru/society/article/55906/. Accessed on 10 March 2017. 
Pravitel'stvo Rossiiskoi Federatsii. 2009. 'Strategiia sotsial'no-ekonomicheskogo razvitiia Dal'nego Vostoka i Baikal'skoga regiona na priod do 2025' [Strategy for the Socioeconomic Development of the Far East and the Baikal Region for the Period until 2025], 28 December. http://old.sakha.gov.ru/node/68499. Accessed on 7 March 2017.

PrimaMedia. 2016. 'Net effektivnosti, net deneg: Minvostok ne smog otstoiat' sredstva na razvitie regiona' [There is no efficiency, no money: Minvostok could not defend funds for the development of the region], 18 November. http://primamedia.ru/news/548538. Accessed on 8 March 2017.

Putin, Vladimir. 2013. 'Poslanie Prezidenta Federal'nomu Sobraniiu' [The President's address to the Federal Assembly], Kremlin.ru, 12 December. http://kremlin.ru/events/president/news/19825. Accessed on 2 February 2017.

RIA Novosti. 2011. 'Istoriia ministerstv po delam natsional'nostei v SSSR i RF' [History of ministries on nationalities in the USSR and the Russian Federation], 15 December. https://ria.ru/spravka/20111215/517534894.html. Accessed on 5 March 2017.

RIA Novosti. 2016. 'Minvostokrazvitiia otkroet podrazdelenie na Kamchatke' [Ministry for the Development of the Far East opens subdivision in Kamchatka], 23 December. https://ria.ru/politics/20161223/1484496251.html. Accessed on 7 February 2017.

Ross, Cameron. 2002. Federalism and democratisation in Russia. Manchester: Manchester University Press

Ross, Cameron. 2010. 'Federalism and inter-governmental relations in Russia', Journal of Communist and Transition Politics 26(2): 165-87.

Rossiiskaia gazeta. 2013. 'O Pravitel'stvennoi komissii po voprosam sotsial'noekonomicheskogo razvitiia Dal'nego Vostoka' [On the State Commission on the Socioeconomic Development of the Far East], 19 September. https:// rg.ru/2013/09/19/dv-komissia-site-dok.html. Accessed on 3 January 2017.

Sakwa, Richard. 2002. 'Federalism, sovereignty and democracy', in Regional politics in Russia, edited by Cameron Ross, 1-22. Manchester: Manchester University Press.

TASS. 2016. 'Aleksandr Galushka: gosprogramma razvitiia Dal'nego Vostoka budet realizovana polnost'iu' [Aleksandr Galushka: the state programme for the Far East will be fully implemented], 24 October. http://tass.ru/opinions/ interviews/3728408. Accessed on 15 March 2017.

Turovskii, Rostislav. 2016. 'Dal'nii Vostok: prioritet Rossiiskoi Federatsii' [The Far East: a priority of the Russian Federation], EastRussia, 27 December. http://www.eastrussia.ru/material/dalniy-vostok-strategicheskiy-prioritetrossiyskogo-gosudarstva. Accessed on 10 February 2017. 
Wegren, Stephen K., Alexander M. Nikulin and Irina Trotsuk. 2015. 'Russia's tilt to Asia and implications for agriculture in the Far East', Eurasian Geography and Economics, 56(2): 127-49.

Zav'ialova, Kseniia. 2012. 'Vladimir Putin raskritikoval rabotu Minvostokrazvitiia' [Vladimir Putin criticized the work of the Ministry for the Development of the Far East], Kommersant, 29 November. http://kommersant.ru/doc/2078790. Accessed on 7 March 2017.

Open Access This chapter is licensed under the terms of the Creative Commons Attribution 4.0 International License (http://creativecommons.org/licenses/ by $/ 4.0 /)$, which permits use, sharing, adaptation, distribution and reproduction in any medium or format, as long as you give appropriate credit to the original author(s) and the source, provide a link to the Creative Commons license and indicate if changes were made.

The images or other third party material in this book are included in the book's Creative Commons license, unless indicated otherwise in a credit line to the material. If material is not included in the book's Creative Commons license and your intended use is not permitted by statutory regulation or exceeds the permitted use, you will need to obtain permission directly from the copyright holder.

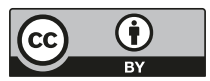

